\title{
PROS PETOS
}

of an edition of the work entitled: "Tawarikhi Ali Seldshuk“, which belongs to the University Library of Leyden No. 419, with an accurate description and historical notes by Dr. W. F. A. Behrnauer.

During my researches of the history of the precursors of the Turkish Empire founded upon the ruins of the empire of the Seldshuks of Iconium, I have found a work much known and important for the history of Oghnzes. I mean the work known by the title: Tawarikhi 'Ali Oghuz, in a manuscript very rare of the University Library of Leyden (No. 419) and which is already described by Prof. Dr. Kuenen in the third volume of the Oriental Manuscripts of the Leyden University Library (No. 942 p. 24). This work (its title is not quoted in the preface and also its author cannot be ascertained), is distributed in three parts: the first (fol. 1-24) treats of the conditions of the old Turks, who draw their origin from Oghuz Khan with a chapter, which contains 24 drawings and which gives a description of the form of the temgha (seal) of the six sons of Oghuz, of their holy birds and the sort of meat eaten at their dinners. The second part (fol. 24-96) treats of the history of the Seldshuks (I will also publish in a separate volume this history in the German language drawn by me from Arabic, Persian and Turkish works) and the accurate history of the Seldshuks who were resident in Persia. The third part finally (fol. 97-277) gives us the detailed description of the bistory of the Seldshuks in Asia minor in a large essay on the administration of the Sultans Ruknuddîn, Ghajâsuddîn and Kaikobâd 'Alâaaddin with a concise description of the nature of the 
dynasty of the Seldshuks of this country. It ends with the life of the Sultan Kaikobâd 'Alầaddin. We do not know what were the events described in the complete work. Though this manuscript is not complete, and a gap is to be found on the folio Nr. $94^{\text {vo }}$ and $95^{\text {ro }}$, it is however very curious and important for the knowledge of the history of the Seldshuks of Asia minor, because in this part of the history the treaties abound not as in the history of the Seldshuks of Persia. The author of this chronicle has availed himself for his work of the history written in this historical part by Muhammed Ibn 'Alî Ibn Sulaimân Arrâwendî, dedicated by hymself to the Sultan Kaikhosrew I. Our author has translated this treaty in the Turkish language, written by Arrâwendi in the Persian language in a country of 'Jrâk and afterwards imported it in Asia minor, where he presented it to the Sultan. Therefore we have no reason to believe this chronicle of the Seldshuks to be a simple translation, because this chronicle is not only cantinued after the death of Râwendî, but because we find many things in it, which he could not have written himself, principally the poems in praise of the Sultan Murad II. We see also from its antiquated style that the quoted Sultan is Sultan Murad II. and we find him directly quoted by his name: Sultan Murad Ben Muhammed Ben Bajazîd. Besides this manuscript, which contains in the beginning a fabulous poem on the prophet Moses, is not only curious and important for the oriental scholars by its antiguated style, because we find here many words of old Turkish origin, which are not used afterwards in Turkish works, and which are not to be found either in dictionaries, but because it gives also many old forms of the Turkish grammar. Its style is simple in its two first parts; the third is however composed in a very bombastic manner of the Persians and Osmanlis, which we see from the nature: of the treaties used by our author. 
This manuscript seems to be written in the $10^{\text {th }}$ century A. H., though it contains no account of its date. I have transcribed it in the year 1862 and the Asiatic Museum of the Imperial Academy of St. Petersburgh has also a copy of it. Its character is a legible naskhi. A known orientalist will have the kindness to execute the autograph of this complete edition. The copy of 65 sheets will cost in England 20 sh. and in America 6 Dollars. All who will purchase it, are requested to send their declaration with their address on the annexed form direct by post to the editor or to the bookseller Mr. C. A. Werner (Schönfeld's Buchhandlung at Dresden).

Dresden, in the month August 1866.

This Label of Subscription on

Copies of the edition of Tawarikhi Ali Seldshuk, published by Dr. W. F. A. Behrnauer, please to sign and send to the editor or to the bookseller C. A. Werner (G. Schönfeld) at Dresden 
DYSENTERY, CHOLERA, FEVER, AGUE, ETC.

\section{CHLORODYNE.}

D. J. COLLIS BROWNE'S CHLORODYNE is a certain Cure in Cholera, Dysentery, Diarrhoea, Colies, \&c.

Dr. J. COLLIS BROWNE'S CHLORODYNE.-Extract from the General Board of Health, London, as to its efficacy in Cholera : "So strongly are we convinced of the immense value of this remedy that we cannot too forcibly urge the necessity of adopting it in all cases." From A. Montgomery, Esq., late Inspector of Hospitals, Bombay : " Chlorodyne is a most valuable remedy in Neuralgia, Asthma, and Dysentery. To it I fairly owe my. restoration to health after eighteen months' severe suffering, and when all other remedies had failed."

Dr. J. COLLIS BROWNE'S CHLORODYNE,-Vice-Chancellor Sir W. Page Wood stated publicly in Court that Dr. J. Collis Browne was undoubtedly the Inventor of Chlorodyne ; that the whole story of the defendant Freeman was deliberately urtrue, and he regretted to say it had been sworn to.-See The Times, July 13, 1864 .

Dr. J. COLLIS BROWNE'S CHLORODYNE.-The Right Hon. Earl Russell communicated to the College of Physicians and J. T. Davenport that that he had received information to the effect that the only remedy of any service in Cholera was Chlorodyne.-See Lancet, Dec. 31, 1864.

Dr. J. COLIIS BROWNE'S CHLORODYNE is the best and most certain remedy in Coughs, Colds, Asthma, Consumption, Neuralgia, Rheumatism, \&c.

Dr. J. COLLIS BROWNE'S CHLORODYNE.-CAUTION.-None genuine without the words "Dr. J. Collis Browne's Chlorodyne" on the Government Stamp. Overwhelming medical testimony accompanies each bottle. Sole Manufacturer, J. T. Davenport, 33, Great Russell-street, Bloomsbury, London. The immense demand enables the Proprietors to reduce the price ; it is now sold in bottles, $1 s .1 \frac{1}{2} d ., 2 s .9 d ., 4 s .6 d$., and $11 s$.

Agents-Calcutra: Scott, Thompson \& Co. ; W. J. Pettar, 74, Clivestreet; New Medical Hall Company. - Bombay: Treacher \& Co. Hong Kong : Mr. A. S. Watson.

J. T. DAVENPORT, 33, Great Russell-street, London, W.C., Sole
IFanufacturer.

Be not misled by the statements of unscrupulous persons, as the

Defendant was termed by the Vice-Chancellor.

THE MOMENTOUS QUESTION.

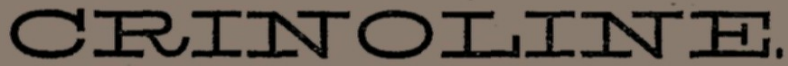

LADIES SHOULD AT ONCE SEE

TFIOMSON'S NEW STYLF,

which-light, graceful, and elegant in outline-combines comfurt and economy with the very latest fashion.

Observe the name "THOMSON," and the Trade Mark "A CROWN."

SOLD EVERYWHERE. 


\section{J. T. B. PORTER \& CO.,}

GAS ENGINEERS, MANUFACTURERS, AND CONTRACTORS,

GOWTS BRIDGE WORKS, LINCOLN, AND

7. JOHN STREET, ADELPHI, LONDON, W.C., MANUFACTURERS OF

PATENT PRIZE PORTABLE,

AND ALL DESCRIPTION OF

GAS APPARATUS

For Mansions, Country Residences, Farm Buildings, Colleries, Manufactories, and all Isolated Buildings, from Ten Lights upwards.

OF PATENT APPARATUS FOR INDIA, \&c.,

For the Manufacturing of Gas from Cotton Seeds and all kinds of Oit.

Contractors for the Erection of Improved Gas Works for Towns,

Villages, \&c. \&c.

ท.13.- Plans, Specitications, and Eostimates on application.

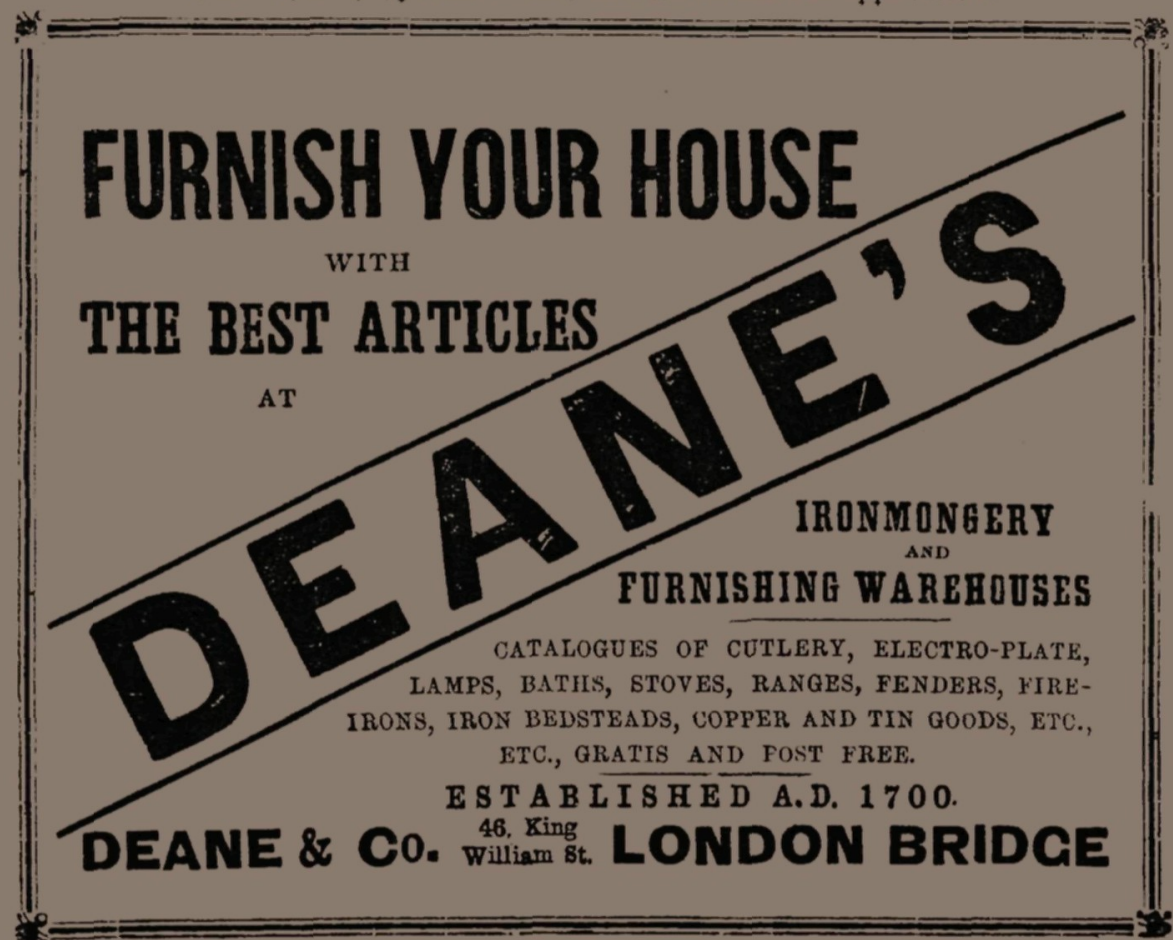

